\title{
Porencephaly and optic hypoplasia in neonatal isoimmune thrombocytopenia
}

\author{
J E DAVIDSON, R C McWILLIAM, T J EVANS, AND J B P STEPHENSON \\ Fraser of Allander Assessment Unit, Royal Hospital for Sick Children, Glasgow
}

SUMMARY Five children with prenatal intracerebral damage associated with neonatal isoimmune thrombocytopenic purpura are described, and characteristic neurological features listed. These include optic hypoplasia which has not been previously documented in this condition.

Neonatal isoimmune thrombocytopenic purpura accounts for $20 \%$ of cases of thrombocytopenia in the newborn. Two per cent of women are platelet antibody $A_{1}$ negative and therefore at risk of an affected pregnancy. ${ }^{1}$

The disease has a mortality of $10-14 \%^{1}$ and haemorrhagic complications are common. Intracerebral lesions are the main cause of mortality and serious morbidity. Perinatal haemorrhage is well recognised. More recently the prenatal development of such lesions has been documented. ${ }^{2-6}$

We describe five children with neonatal isoimmune thrombocytopenic purpura and porencephaly as a result of prenatal intracerebral damage.

\section{Case reports}

Details of the five cases are shown in tables 1 and 2 . All infants developed skin purpura shortly after delivery and were found to be severely thrombocytopenic. All had proved neonatal isoimmune thrombocytopenic purpura, and other causes of thrombocytopenia were excluded.

CASE 1

This infant had an intracranial haemorrhage in the immediate prenatal period. After an atraumatic delivery she presented aged 2 hours with evidence of neurological abnormality. Cranial ultrasonography showed two haemorrhagic lesions in the right frontoparietal region. There was central resolution of these lesions, the appearances being consistent with haemorrhage several days previously. Apart from transient neonatal seizures she has had no other neurological or developmental problems.

CASES $2-5$

Cases 2-5 present a different picture. Despite severe thrombocytopenia, none had evidence of a perinatal intracranial bleed. All have subsequently presented with serious neurological problems, and a characteristic clinical picture. This consists of porencephaly with or without communicating hydrocephalus, visual impairment with optic hypoplasia, mental handicap, and a variable degree of cerebral palsy. All must have had a prenatal intracerebral vascular event.

Case 5 is of particular interest as the diagnosis of neonatal isoimmune thrombocytopenic purpura was made retrospectively when he was 10 years old. He had neonatal thrombocytopenia of unknown aetiology, and later presented with visual impairment. He had had the characteristic features described above, and we confirmed the diagnosis of neonatal isoimmune thrombocytopenic purpura serologically.

\section{Discussion}

The recognition that intracerebral lesions may occur prenatally in patients with neonatal isoimmune thrombocytopenic purpura has important implications for the further understanding of this condition and for the management of affected pregnancies. Though a number of such cases have now been reported there is no information regarding the incidence, mechanism, and neurological consequences of these lesions.

We have described five infants with neonatal isoimmune thrombocytopenic purpura and porencephaly resulting from prenatal damage. One had an intracranial haemorrhage in the immediate prenatal period. In the other four, severe neurological damage was the result of an intracerebral event that occurred earlier in pregnancy. These earlier lesions give rise to a characteristic pattern of neurological abnormality including optic hypoplasia, which has not previously been described in this disease. Interestingly, one previous case report of congenital porencephaly in two siblings with neonatal isoimmune thrombocytopenic purpura documents similar features, although they describe optic atrophy rather than optic hypoplasia. ${ }^{6}$ Examination of our patients clearly indicated that the optic nerves were hypoplastic rather than simply atrophic. The presence of optic hypoplasia is difficult to explain as the result of a 
Table 1 Neonatal data

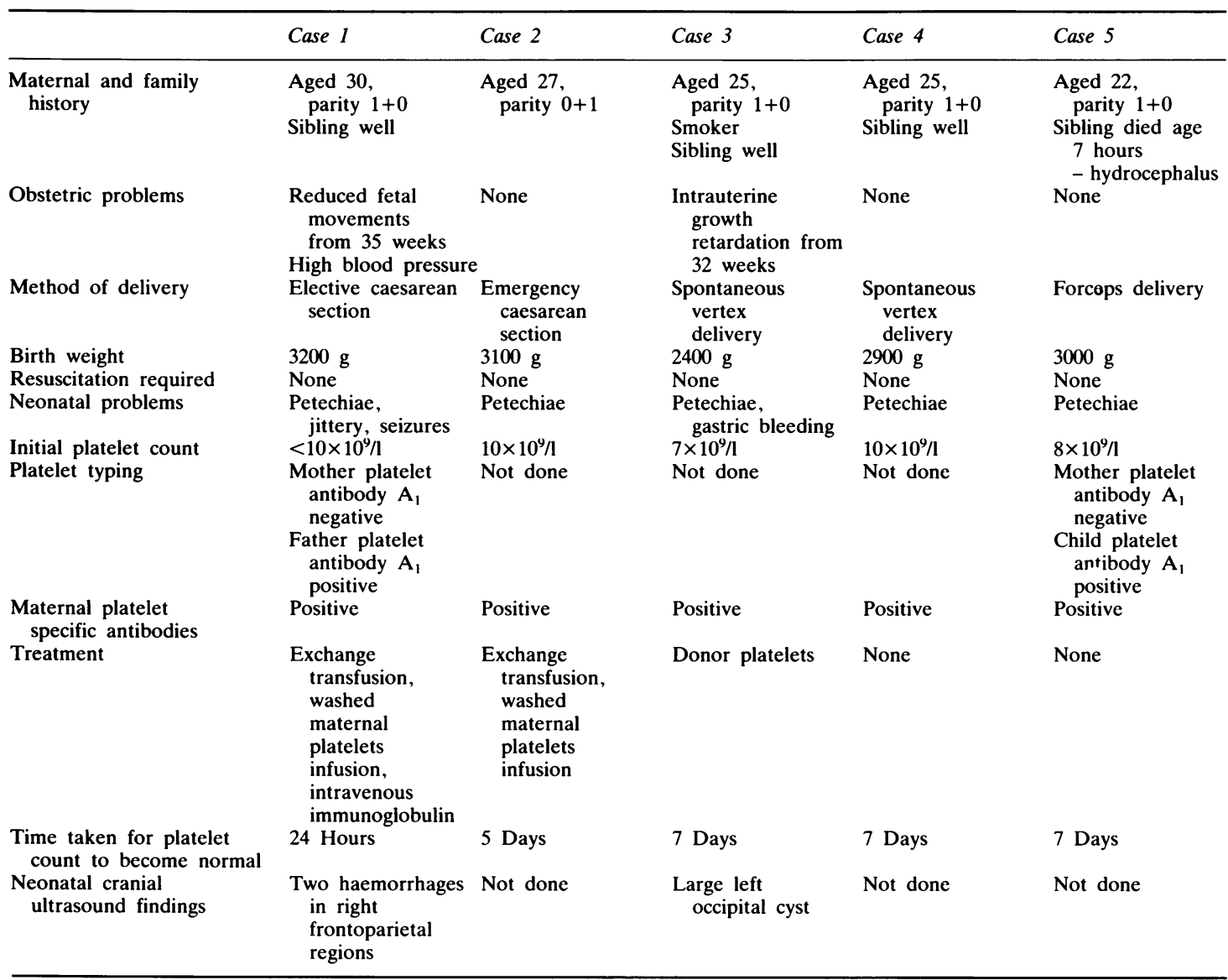

Table 2 Follow up data

\begin{tabular}{|c|c|c|c|c|c|}
\hline & Case 1 & Case 2 & Case 3 & Case 4 & Case 5 \\
\hline Presentation & $\begin{array}{l}\text { Routine } \\
\quad \text { follow up }\end{array}$ & Age 2 months & Age 2 months & Age 6 weeks & Age 5 months \\
\hline Neurological features & Normal & $\begin{array}{l}\text { Visual handicap, } \\
\text { spastic diparesis, } \\
\text { mental handicap, } \\
\text { seizures }\end{array}$ & $\begin{array}{l}\text { Visual handicap, } \\
\text { spastic diparesis, } \\
\text { mental handicap } \\
\text { feeding problems }\end{array}$ & $\begin{array}{l}\text { Visual handicap, } \\
\text { spastic quadriplegia, } \\
\text { mental handicap, } \\
\text { seizures }\end{array}$ & $\begin{array}{l}\text { Visual handicap, } \\
\text { spastic diparesis, } \\
\text { mental handicap, } \\
\text { language delay }\end{array}$ \\
\hline $\begin{array}{l}\text { Cranial ultrasound } \\
\text { findings }\end{array}$ & $\begin{array}{l}\text { Right } \\
\text { frontoparietal } \\
\text { porencephalic } \\
\text { cysts }\end{array}$ & $\begin{array}{l}\text { Left temporal } \\
\text { and right occipital } \\
\text { porencephalic cysts }\end{array}$ & $\begin{array}{l}\text { Left temporal } \\
\text { and cerebellar } \\
\text { porencephalic cysts }\end{array}$ & $\begin{array}{l}\text { Massive hydrocephalus } \\
\text { and left parietal } \\
\text { porencephalic cyst }\end{array}$ & Not done \\
\hline $\begin{array}{l}\text { Computed tomographic } \\
\text { findings }\end{array}$ & Not done & $\begin{array}{l}\text { Above with } \\
\text { communicating } \\
\text { hydrocephalus }\end{array}$ & $\begin{array}{l}\text { Above with } \\
\text { communicating } \\
\text { hydrocephalus }\end{array}$ & Not done & $\begin{array}{l}\text { Right occipital } \\
\text { porencephalic cyst }\end{array}$ \\
\hline
\end{tabular}


haemorrhagic lesion, and the possibility that the primary event may have been ischaemic or thromboembolic requires investigation.

We suggest that intracerebral damage in neonatal isoimmune thrombocytopenic purpura may arise in three different ways. Perinatal haemorrhage may occur as a result of birth trauma. Spontaneous haemorrhage may occur prenatally secondary to severe thrombocytopenia (as in case 1). Finally, earlier prenatal lesions may occur giving rise to the neurological features we have described.

The relative incidence of these lesions is unknown; our experience with five cases suggests that prenatal lesions may be more common than previously thought. Further investigation of the mechanism of the earlier prenatal lesions is required as there are important implications for obstetric management. Regular antenatal ultrasound screening in pregnancies thought to be affected may give further information about the nature and timing of events.

Because the purpura is transient, neonatal isoimmune thrombocytopenic purpura may remain undiagnosed in the neonatal period. Some unexplained cases of porencephaly may therefore be the result of prenatal damage in neonatal isoimmune thrombocytopenic purpura (case 5). We looked at a further five children with unexplained porencephaly and carried out platelet typing of mother and child; in no case was there evidence of platelet incompatibility. Nevertheless, neonatal isoimmune thrombocytopenic purpura should be considered as a possible diagnosis in unexplained porencephaly, particularly if it is associated with optic hypoplasia.

In conclusion, prenatal intracerebral lesions occur in association with neonatal isoimmune thrombocytopenic purpura and give rise to a characteristic pattern of neurological abnormality, including optic hypoplasia. Further clarification of the mechanism of these lesions is required.

We thank Dr R Crawford and the Blood Transfusion Service, Law Hospital for their help.

\section{References}

' Patriarco M, Yeh S. Immunological thrombocytopenia in pregnancy. Obstet Gynecol Surv 1986;41:661-71.

2 Zalneraitis EL, Young RSK, Krishnamoorthy KS. Intracerebral hemorrhage in utero as a complication of isoimmune thrombocytopenia. J Pediatr 1979;95:611-4.

3 Magny JF, Vial M, Bessis R, et al. Hémorragie cérébrale anténatale et incompatibilité plaquettaire foeto-maternelle. Arch Fr Pediatr 1984;41:711-2.

${ }^{4}$ Morales WJ, Stroup M. Intracranial hemorrhage in utero due to isoimmune neonatal thrombocytopenia. Obstet Gynecol 1985;65:20s-1.

5 De Vries LS, Connell J, Bydder GM, et al. Recurrent intracranial haemorrhages in utero in an infant with alloimmune thrombocytopenia. Case report. Br J Obstet Gynaecol 1988;95:299-302.

6 Friedman JM, Aster RH. Neonatal alloimmune thrombocytopenic purpura and congenital porencephaly in two siblings associated with a 'new' maternal antiplatelet antibody. Blood 1985;65:1412-5.

Correspondence to Dr JE Davidson, Department of Pathology, Western Infirmary, Glasgow G11 6NT.

Accepted 25 January 1989

\section{Flecainide toxicity}

\section{G A B RUSSELL AND R P MARTIN}

Department of Paediatric Cardiology, Royal Liverpool Children's Hospital

SUMmary Flecainide toxicity occurred in an infant being treated for refractory atrioventricular re-entry tachycardia. Ventricular tachycardia developed when dextrose was substituted for milk feeds. We believe that milk was interfering with the absorption of flecainide, and so a high serum concentration developed when milk feeds were stopped.

Flecainide acetate is a comparatively new drug for the treatment of supraventricular and ventricular arrhythmias. Early clinical experience in infants and children has shown that it is effective and well tolerated. $^{12}$

\section{Case report}

A baby boy was born at 34 weeks' gestation after an apparently uncomplicated pregnancy. He was hydropic at birth, weighing $3100 \mathrm{~g}$ (>90th centile). Resuscitation with endotracheal intubation was required, and mechanical ventilation was continued for three days. After extubation he remained cyanosed and a hyperoxic test confirmed the presence of an appreciable right to left shunt. Standard investigations did not identify a cause for the hydrops fetalis, and he was referred for cardiological assessment.

On transfer to our hospital at 6 days of age he weighed $2100 \mathrm{~g}$ and was no longer hydropic. He 